\title{
Correction to: Opportunistic spongivore fishes in a reef of Gulf of Mannar, India
}

\author{
Jonathan Samuel Emmett $\mathbb{D} \cdot$ K. Diraviya Raj • \\ G. Mathews · R. L. Laju
}

Published online: 27 October 2021

(C) Springer Nature B.V. 2021

\section{Correction to: Environ Biol Fish (2021) affiliations.}

104:1251-1262

https://doi.org/10.1007/s10641-021-01150-3

Details were missing in the acknowledgement section of the original published version of this article. Following is the full acknowledgment section.

\section{Acknowledgement}

The authors are thankful to Science and Engineering Research Board (SERB), Department of Science and Technology, Government of India for funding support (DST-SERB Sanction order No. EMR/2017/002S10); to the Chief Wildlife Warden, Tamil Nadu Forest Department and Wildlife Warden, Gulf of Mannar Marine National Park, Government of Tamil Nadu for research permissions; and to the Suganthi Devadason Marine Research Institute for logistical support.

Publisher's Note Springer Nature remains neutral with regard to jurisdictional claims in published maps and institutional

The original article can be found online at https://doi.org/ 10.1007/s10641-021-01150-3.

J. S. Emmett $(\bowtie) \cdot$ K. D. Raj · G. Mathews · R. L. Laju Suganthi Devadason Marine Research Institute, 44-Beach, Road, Tuticorin 628 001, Tamil Nadu, India

e-mail: jonathanemmett@live.com

J. S. Emmett

Registration No. 19217022241001, Manonmaniam,

Sundaranar University, Tirunelveli, India 